Tersedia online di: http://ejournal-balitbang.kkp.go.id/index.php/JP
e-mail:jurnalpari@gmail.com
JURNAL PARI
Volume 3 Nomor 2 Desember 2017
p-ISSN: 2502-0730
e-ISSN : 2549-0133

\title{
KEILMUAN PENDUKUNG ILMU PERPUSTAKAAN UNTUK MEWUJUDKAN PERPUSTAKAAN YANG IDEAL
}

Part of library support science to realize the ideal library

\section{SUYATNO}

Pusat Riset Perikanan

Diterima tanggal : 29 Agustus 2017 diterima setelah perbaikan : 19 Oktober 2017 disetujui terbit : 1 Desember 2017

\begin{abstract}
ABSTRAK
Perpustakaan tidak bisa berdiri sendiri tanpa adanya dukungungan dari keilmuan lain. IImu pendukung perpustakaan digunakan sesuai fungsinya disuatu lembaga perpustakaan yang akan bersatu padu dalam mengembangankan sebuah perpustakaan sehingga terwujud sebuah perpustakaan yang ideal. Beberapa keilmuan utama yang mendukung ilmu perpustakaan antara lain bidang manajemen, bidang teknologi informasi, bidang komunikasi, bidang pemasaran, bidang hukum, bidang akuntansi, bidang desain grafis, bidang tata bahasa dan lain sebagainya. Semua bidang keilmuan tersebut akan saling menunjang satu dengan lainya. Tujuan dari penulisan ini adalah untuk mengetahui bidang ilmu apa saja yang dibutuhkan untuk membangun suatu perpustakaan yang ideal. Sebenarnya banyak sekali keilmuan pendukung untuk mengelola suatu perpustakaan akan tetapi hanya sebagian besar saja yang akan dibahas dalam tulisan ini.
\end{abstract}

Kata Kunci: keilmuan pendukung; ilmu perpustakaan, perpustakaan ideal

\section{ABSTRACT}

The library can not stand alone without the support of other scholars. Science library support is used according to its function in a library institution that will unite in mengembangankan a library to realize an ideal library. Some of the main scholarships that support library science include management, information technology, communications, marketing, law, accounting, graphic design, grammar and so on. All these disciplines will support each other. The purpose of this paper is to know what science is needed to build an ideal library. Actually a lot of supporting scholarship to manage a library but only most of which will be discussed in this paper.

Keywords: Supporting scholarship; Library science, ideal library 


\section{PENDAHULUAN}

Kata ilmu berasal dari bahasa Arab : 'Alima, ya'lamu, ilman, yang berarti : mengerti, memahami benar-benar. Dalam bahasa Inggris disebut science (pengetahuan).

https://afidburhanuddin.wordpress. com/2013/09/23/dasar-dasar-keilmuan/

Prof. DR. M. J.Langerveld, Guru Besar pada Pijk Universiteit di U trecht (Belanda), mengatakan bahwa " pengetahuan ialah kesatuan objek yang mengetahui dan objek yang diketahui. Suatu kesatuan dalam mana objek itu dipandang oleh subjek sebagai diketahuinya. Pada akhirnya mereka merumuskan ilmu pengetahuan" kumpulan pengetahuan mengenai suatu hal (objek/ lapangan), yang merupakan kesatuan yang sistematis dan memberikan penjelasan yang sistematis yang dapat dipertanggungjawabkan sebab-sebab hal/ kejadian itu."

Menurut kamus besar Bahasa Indonesia (Depdikbud 1988), ilmu memiliki pengertian, yaitu: IImu adalah suatu pengetahuan tentang suatu bidang yang disusun secara bersistem menurut metode-metode tertentu, yang dapat digunakan untuk menerapkan gejala-gejala tertentu dibidang (pengetahuan) tersebut, seperti ilmu hukum, ilmu pendidikan, ilmu ekonomi dan sebagainya.

IImu, sains, atau ilmu pengetahuan adalah seluruh usaha sadar untuk menyelidiki, menemukan, dan meningkatkan pemahaman manusia dari berbagai segi kenyataan dalam alam manusia. Segi-segi ini dibatasi agar dihasilkan rumusanrumusan yang pasti. IImu memberikan kepastian dengan membatasi lingkup pandangannya, dan kepastian ilmu-ilmu diperoleh dari keterbatasannya.

IImu bukan sekadar pengetahuan (knowledge), tetapi merangkum sekumpulan pengetahuan berdasarkan teori-teori yang disepakati dan dapat secara sistematik diuji dengan seperangkat metode yang diakui dalam bidang ilmu tertentu. Dipandang dari sudut filsafat, ilmu terbentuk karena manusia berusaha berpikir lebih jauh mengenai pengetahuan yang dimilikinya. IImu pengetahuan adalah produk dari epistemologi. https://id.wikipedia.org/wiki/llmu

IImu Perpustakaan (Inggris: library science) atau IImu Informasi adalah bidang interdisipliner yang menggabungkan ilmu sosial, ilmu hukum, dan ilmu terapan untuk mempelajari topik yang berkaitan dengan perpustakaan. IImu perpustakaan ini mempelajari mengenai cara pengumpulan, pengorganisasian, pengawetan, dan penyebarluasan sumber informasi yang ada di suatu perpustakaan, serta berkaitan dengan nilai ekonomi dan politis dari informasi pada umumnya. https://id.wikipedia.org/wiki/llmu_ perpustakaan

Secara akademis, mata kuliah dalam ilmu perpustakaan biasanya meliputi: manajemen koleksi, sistem informasi dan teknologi, kataloging, klasifikasi, cara pengawetan, referensi, statistika dan manajemen. IImu perpustakaan juga berkembang sejalan dengan perkembangan teknologi komputer, oleh karena itu topik tentang sistem informasi manajemen, manajemen basis data, arsitektur informasi, dan manajemen pengetahuan juga menjadi bagian mata kuliah penting dalam pembahasan ilmu perpustakaan menuju suatu perpustakaan digital. IImu Perpustakaan biasanya juga berhubungan dengan dokumentasi dan kearsipan. IImu ini juga dapat diterapkan dalam pengelompokan data. https://id.wikipedia.org/wiki/llmu_perpustakaan

IImu atau keilmuan pendukung perpustakaan adalah keilmuan yang digunakan untukmendukung proses berjalanya suatu perpustakaan sehingga menjadi sebuah perpustakaan yang ideal.

\section{PEMBAHASAN}

Dalam mengembangangkan sebuah perpustakaan perlu didukung oleh beberapa keilmuan sehingga tercipta sebuah perpustakaan yang ideal. Menurut http://www.syedara.com/2014/04/10kriteria-perpustakaan-yang-ideal/ Perpustakaan bisa disebut ideal bila memenuhi persayaratan sebagai berikut;

1. Professional

2. Menguasai IT

3. Performa yang bagus

4. Inovatif

5. Mampu melaksanakan manajemen informasi perpustakaan

6. User oriented

7. Santun dan tegas terhadap pelanggaran

8. Sepesial day to user

9. Pandai dalam menggalang dana

10. Dirindukan pengguna dan masyarakat sekitanrnya

Selain persayaratan diatas masih ada beberapa yang harus ditambahkan yaitu: 
1. Desain gedung perpustakaan

2. Jumlah tenaga pustakawan

3. Jumlah koleksi yang dimiliki

4. Kerjasama dengan unit perpustakaan lain

5. Kesejahteraan pegawai harus diperhatikan Keilmuan yang mendukung atau yang lebih tepatnya yang dipakai dalam menjalankan sebuah unit perpustakaan antara lain;

\section{Ilmu Manajemen}

Secara etimologi Kata Manajemen berasal dari bahasa Perancis kuno ménagement, yang memiliki arti "seni melaksanakan dan mengatur." Kata manajemen mungkin berasal dari bahasa Italia (1561) maneggiare yang berarti "mengendalikan," terutama dalam konteks mengendalikan kuda, yang berasal dari bahasa latin manus yang berarti "tangan". Bahasa Prancis lalu mengadopsi kata ini dari bahasa Inggris menjadi ménagement, yang memiliki arti seni melaksanakan dan mengatur.

ht t ps://id.wikipedia.org/wiki/ Manajemen\#Etimologi

Menurut Wikipedia.org. Manajemen adalah seni menyelesaikan pekerjaan melalui orang lain. Definisi Mary ParkerFolletiniberartibahwa seorang manajer bertugas mengatur dan mengarahkan orang lain untuk mencapai tujuan organisasi. Ricky W. Griffin mendefinisikan manajemen sebagai sebuah proses perencanaan, pengorganisasian, pengkoordinasian, dan pengontrolan sumber daya untuk mencapai sasaran secara efektif dan efesien. Efektif berarti bahwa tujuan dapat dicapai sesuai dengan perencanaan, sementara efisien berarti bahwa tugas yang ada dilaksanakan secara benar, terorganisir, dan sesuai dengan jadwal. Manajemen belum memiliki definisi yang mapan dan diterima secara universal. https:// id.wikipedia.org/wiki/Manajemen

\section{Teknologi Informasi}

Teknologi Informasi (TI), atau dalam bahasa Inggris dikenal dengan istilah Information technology (IT) adalah istilah umum untuk teknologi apa pun yang membantu manusia dalam membuat, mengubah, menyimpan, mengomunikasikan dan/atau menyebarkan informasi. TI menyatukan komputasi dan komunikasi berkecepatan tinggi untuk data, suara, dan video. Contoh dari Teknologi Informasi bukan hanya berupa komputer pribadi, tetapi juga telepon, TV, peralatan rumah tangga elektronik, dan peranti genggam modern (misalnya ponsel) https://id.wikipedia.org/wiki/Teknologi_informasi

Sedangkan teknologi informasi di perpustakaan biasanya lebih dikenal dengan perpustakaan digital yaitu perpustakaan dengan system informasi manajemen menggunakan teknologi nformasi ditambah koleksi-koleksi digital baik berupa jurnal, ebook, CD audio, maupun koleksi video (Supriyanto, 2008)

Teknologi informasi di perpustakaan mempunyai peran yang sangat penting karea hamir mencakup semua kegiatan di perpustakaan menggunkan teknologi informasi dari mulai kegiatan pengolahan, layanan, OPAC, sampai kegiatan sirkulasi yang merupakan kegatan utama dalam suatu perpustakaan.

Manfaat yang diperoleh menurut (Supriyanto, 2008) dari penggunaan teknologi informasi di perpustakaan antara lain:

1. Mengefisiensikan dan mempermudah pekerjaan dalam perpustakaan

2. Memberikan layanan yang lebih baik kepada pengguna perpustakaan

3. Meningkatkan citra perpustakaan

4. Pengembangan infrastruktur nasional, regional, dan global

Selain itu teknologi informasi di perpustakaan juga dapat menghemat ruangan perpustakaan karena koleksinya sudah berbentuk digital. Walaupun koleksi tercetaknya masih dibutuhkan tetapi minimal masih bisa mengurangi jumlah eksemplarnya. Teknologi informasi juga dapat mengurangi penggunaan kertas/paperless

\section{Ilmu Komunikasi}

Komunikasi adalah Proses di mana pemikiran dan pemahaman disampaikan antar individu, atau antar organisasi dengan individu. Komunikasi sebagai proses penyampaian pesan yang merupakan gagasan atau informasi pengirim melalui suatu media kepada penerima agar mampu memahami maksud pengirim.

https://id.wikipedia.org/wiki/Komunikasi_ pemasaran

IImu komunikasi adalah ilmu yang mempelajari cara-cara untuk mentransfer ide dari satu individu ataupun grup ke individu atau grup yang lain. Proses transfer itu sendiri bisa melalui media tertulis, lisan, maupun media-media yang lain. 
http://muthiofficial.blogspot.co.id/2013/01/sekilastentang-ilmu-komunikasi.html

Dalam pengembangan perpustakaan ilmu komomunikasi diterapkan hampir diseluruh aspek kegiatan perpustakaan antra lain:

\section{Kegiatan pengadaan}

Kegiatan pengadaan sangat membutuhkan adanya komunikasi yang baik antara beberapa pihak diantaranya pihak pengelola dengan pemakai yaitu komunikasi dalam menentukan koleksi apa saja yang dibutuhkan oleh pemakai sehingga koleksi yang akan diadakan tidak percuma atau dapat termanfaatkan dengan baik. Selain itu komunikasi antara pemimpin di unit perpustakan dengan pengelola perpustakaan juga dibutuhkan dalam proses pengadaan yaitu komunikasi masalah berapa banyak koleksi yang akan dibeli, pemilihan rekanan, penggunaan anggaran dan lain sebagainya.

\section{Pengolahan Bahan Pustaka}

Kegiatan pengolahan bahan pustaka juga tidak lepas dari peran ilmu komunikasi. Hal ini dapat dilihat dari pembagian tugas yang dilakukan oleh pimpinan unit perpustakaan terhadap staf tau karyawan pengelola perpustakaan dalam kegiatan pengelolaan bahan pustaka. Selain itu komunikasi antar staf di perpustakaan juga terjadi pada saat pembagian tugas sesuai dengan bidangnya masing-masing sehingga tidak terjadi kesalahan dalam pengolahan bahan pustaka.

\section{Kegiatan Pelayanan}

Komunikasi yang terjadi di bidang pelayanan antara lain komunikasi antra petugas perpustakaan dengan pemakai atau pengunjung. Ini dilakukan biasanya pada saat menanyakan informasi yang akan dicari. Kemudian setelah mendapatkan informasi yang dicari biasanya akan berlanjut ke proses peminjaman atau mungkin jika koleksi yang dicari berupa koleksi referensi maka akan dilakukan fotokopi. Dalam proses tersebut biasanya sering terjadi komunikasi yang aktif antara petugas dengan pengunjung, disinilah petugas dituntut untuk bisa berkomunikasi sebaik mungkin dengan pengunjung.

Tata bahasa yang digunakan harus sopan tidak membuat pengunjung marah, penampilan harus rapi, raut muka harus selalu tersenyum sehingga membuat pengunjung merasa senang dan betah.
Tentunya masih banyak lagi kegiatan komunikasi yang dibutuhkan di perpustakaan selain dari tiga kegiatan diatas.

\section{Ilmu bahasa dan budaya}

Bahasa (dari bahasa Sanskerta) adalah kemampuan yang dimiliki manusia untuk berkomunikasi dengan manusia lainnya menggunakan tanda, misalnya kata dan gerakan. Kajian ilmiah bahasa disebut ilmu linguistik.

https://id.wikipedia.org/wiki/Bahasa

Kebudayaan adalah sistem simbol yang terdiri dari simbol - simbol dan makna - makna yang dimiliki bersama, dan bersifat publik (Saifuddin, 2005)

Bahasa dan budaya adalah dua hal yang berbeda tetapi keduanya memiliki hubungan yang sangat erat dan tidak bisa dipisahkan satu sama lainya. Bahasa merupakan ciri dan identitas dari pembawa budaya tersebut. Untuk memperkenalkan suatu budaya yang dimiliki oleh masyarakat kepada masyarakat lainnya apalagi jika sudah berbeda suku, berbeda daerah sampai berbeda bangsa serta negaranya bahasa mutlak diperlukan khususnya bahasa internasional yaitu bahasa inggris. Jadi kesimpulanya suatu budaya tidak bisa terlepas dari peran bahasa.

Hubungannya dengan perpustakaan bahasa dan budayajuga sama yaitu menjadi bagian penting dari perpustakaan baik dilihat dari segi koleksi maupun dari pengunjung perpustakaan yang berasal dari berbagai daerah dan Negara. Koleksi diperpustakaan khususnya di perpustakaan umum suatu daerah atau Negara biasanya memiliki koleksi yang menggunakan bahasa dan budaya yang berbeda-beda. Dari segi pengunjung juga dapat dilihat semakin besar danlengkap suatu perpustakaan maka pengunjungnya bisa berassal dari berbagai daerah atau Negara dengan bahasa dan budaya yang berbeda pula. Oleh karena itu ilmu bahasa dan budaya mutlak diperlukan di perpustakaan yang harus dimiliki oleh semua pengelola perpustakaan.

\section{Desain}

Desain biasa diterjemahkan sebagai seni terapan, arsitektur, dan berbagai pencapaian kreatif lainnya. Dalam sebuah kalimat, kata "desain" bisa digunakan, baik sebagai kata benda maupun kata kerja. Sebagai kata kerja, "desain" memiliki arti "proses untuk membuat dan 
menciptakan obyek baru". Sebagai kata benda, "desain" digunakan untuk menyebut hasil akhir dari sebuah proses kreatif, baik itu berwujud sebuah rencana, proposal, atau berbentuk benda nyata. https://id.wikipedia.org/wiki/Desain

Proses desain pada umumnya memperhitungkan aspek fungsi, estetika, dan berbagai macam aspek lainnya dengan sumber data yang didapatkan dari riset, pemikiran, brainstorming, maupun dari desain yang sudah ada sebelumnya. Akhir-akhir ini, proses (secara umum) juga dianggap sebagai produk dari desain, sehingga muncul istilah "perancangan proses". Salah satu contoh dari perancangan proses adalah perancangan proses dalam industri kimia.

IImu desain atau arsitektur di perpustakaan biasanya digunakan untuk membangun gedung perpustakaan agar terlihat menarik dan unik serta inovatif sehingga pengunjung akan tertarik dan senang dating ke perpustakaan. Selain untuk keperluan pembangunan gedung desain juga digunakan dalam penataan koleksi, serta rakrak buku di perpustakaan. Ini bertujuan agar ruang perpustakaan tertata rapi dan juga menarik nyaman untuk membaca dan dari segi biaya pembangunannya tidak memerlukan banyak biaya.

\section{KESIMPULAN}

Selain keilmuan yang sudah dibahas diatas sebenarnya masih banyak bidang keilmuan yang tidak kalah penting dengan keilmuan yang sudah penulis jelaskan. Akan tetapi penulis hanya membahas sebagian saja dari keilmuan yang mendukung berdirinya sebuah perpustakaan yaitu keilmuan bidang manajemen, bidang teknologi informasi, bidang komunikasi, bidang bahasa dan budaya serta bidang desain. Bidang keilmuan tersebut tidak bisa terlepas peranannya dari perpustakaan karena masingmasing bidang mempunyai fungsinya masingmasing dalam mendukung berdirinya sebuah perpustakaan. Kedepanya diharapkan penulis bisa menambahkan berbagai bidang keilmuan yang lain yang mendukung keberadaan suatu perpustakaan.

\section{DAFTAR PUSTAKA}

https://afidburhanuddin.wordpress. com/2013/09/23/dasar-dasar-keilmuan/

https://id.wikipedia.org/wiki/lImu

https://id.wikipedia.org/wiki/llmu_perpustakaan

http://www. syedara.com/2014/04/10-kriteriaperpustakaan-yang-ideal/

Supriyanto, W. Muhsin, A. 2008. Teknologi Informasi Perpustakaan: strategi perancangan perpustakaan digital. Yogyakarta: Kanisius

\section{https://id.wikipedia.org/wiki/} Manajemen\#Etimologi

https://id.wikipedia.org/wiki/Manajemen

https://id.wikipedia.org/wiki/Teknologi_informasi

Saifuddin, A.F. 2005. Antopologi Kontemporer: Suatu pengantar kritis mengenai paradigma. Jakarta: Prenada Media

https://id.wikipedia.org/wiki/Komunikasi pemasaran

http://muthiofficial.blogspot.co.id/2013/01/sekilastentang-ilmu-komunikasi.html

https://id.wikipedia.org/wiki/Bahasa

https://id.wikipedia.org/wiki/Desain 
